\title{
Penerapan Model Pembelajaran Tuntas Dengan Metode Tutor Sebaya Untuk Meningkatkan Hasil Belajar Matematika Siswa SMP
}

\author{
Khusnul Khotimah $^{1, \text { a) }}$, Rita Yuliastuti ${ }^{1}$ \\ ${ }^{1}$ Universitas PGRI Rongolawe \\ a) ritayuliastuti1207@gmail.com
}

\begin{abstract}
This research is motivated by the low student mathematics learning outcomes. The reason is the lack of full delivery of lessons and students have not fully understood the material. One alternative to overcome this problem is to implement a complete learning model with peer tutoring methods. The purpose of this study: 1) to describe the improvement of students 'mathematics learning outcomes through the application of a complete learning model with material peer tutoring methods to construct flat-side space for junior high school students, 2) to describe students' responses to the application of the complete learning model with peer tutoring methods. classroom action research with quantitative and qualitative descriptive analysis. Research location in Tuban 7th Middle School. The subjects studied were students of class VIII E. The instruments used were learning outcome evaluation test sheets and student response questionnaires. The results of the study concluded that students' mathematics learning outcomes in the application of the complete learning model with peer tutoring methods had increased. This can be seen from the average student learning outcomes of the first cycle of 88 , the second cycle of 89 and the third cycle of 97 . So there is an increase in the average mathematics learning outcomes in the first cycle to the second cycle of 1 and from cycle II to cycle III amounting to 8 . And the percentage of classical completeness in cycles I, II and III reaches $100 \%$. While the student response to the application of the complete learning model with peer tutors is included in the criteria very effective, with a percentage of positive responses of $96 \%$ and the percentage of negative responses of $4 \%$.
\end{abstract}

Keywords: mastery learning, peer tutoring, mathematics learning outcomes

\begin{abstract}
Abstrak. Penelitian ini dilatar belakangi oleh rendahnya hasil belajar matematika siswa. Penyebabnya adalah kurangnya penyampaian pelajaran secara penuh dan siswa belum memahami materi secara tuntas. Salah satu alternatif untuk mengatasi hal tersebut adalah menerapkan model pembelajaran tuntas dengan metode tutor sebaya. Tujuan penelitian ini: 1) untuk mendeskripsikan peningkatan hasil belajar matematika siswa melalui penerapan model pembelajaran tuntas dengan metode tutor sebaya materi bangun ruang sisi datar siswa SMP, 2) untuk mendeskripsikan respon siswa terhadap penerapan model pembelajaran tuntas dengan metode tutor sebaya. Jenis penelitian ini adalah penelitian tindakan kelas dengan analisis deskriptif kuantitatif dan kualitatif. Lokasi penelitian di SMP Negeri 7 Tuban. Subjek yang diteliti adalah siswa kelas VIII E. Instrumen yang digunakan adalah lembar tes evaluasi hasil belajar dan angket respon siswa. Hasil penelitian diperoleh kesimpulan bahwa hasil belajar matematika siswa dalam penerapan model pembelajaran tuntas dengan metode tutor sebaya mengalami peningkatan. Hal ini dapat dilihat dari rata-rata hasil belajar siswa dari siklus I sebesar 88, siklus II sebesar 89 dan siklus III sebesar 97. Jadi ada peningkatan rata-rata hasil belajar matematika pada siklus I ke siklus II sebesar 1 dan dari siklus II ke siklus III sebesar 8. Serta persentase ketuntasan klasikal pada siklus I, II dan III mencapai $100 \%$. Sedangkan respon siswa terhadap penerapan model pembelajaran tuntas dengan tutor sebaya termasuk dalam kriteria sangat efektif, dengan persentase respon positif sebesar $96 \%$ dan persentase respon negatif sebesar $4 \%$.
\end{abstract}

Kata kunci: model pembelajaran tuntas, metode tutor sebaya, hasil belajar matematika 


\section{PENDAHULUAN}

Pendidikan adalah salah satu usaha untuk meningkatkan dan mengembangkan sumber daya manusia melalui kegiatan pembelajaran (Purba, 2013). Sedangkan menurut Indrianie (2015), pembelajaran ibarat jantung dari proses pendidikan. Proses pembelajaran yang baik cenderung menghasilkan lulusan dengan hasil belajar yang baik, demikian pula sebaliknya Ulandari, Putri, Ningsih \& Putra, 2019). Oleh karena itu, proses pembelajaran merupakan salah satu unsur penentu baik tidaknya lulusan yang dihasilkan oleh suatu sistem pendidikan. Namun dalam proses pembelajaran masih banyak terjadi permasalahan. Salah satu masalah pendidikan yang masih banyak terjadi di Indonesia adalah bahwa model dan metode dalam proses pembelajaran masih di dominasi peran guru, sehingga keaktifan siswa masih sangat rendah.

Berdasarkan observasi yang telah dilakukan di SMP Negeri 7 Tuban, bahwa selama ini guru masih menggunakan model pembelajaran langsung dimana guru hanya memberikan ceramah tentang materi yang disampaikan selama proses pembelajaran berlangsung sehingga siswa merasa bosan dan kurang memperhatikan guru selama proses pembelajaran. Aktivitas yang dilakukan siswa biasanya hanya mendengar dan mencatat, siswa jarang mengemukakan pendapat atau bertanya kepada guru meskipun sebenarnya belum mengerti materi yang disampaikan oleh guru. Hal tersebut memberikan dampak terhadap hasil belajar siswa yang relatif masih rendah karena sebagian besar nilai rata-rata siswa masih dibawah KKM. Hasil belajar siswa pada mata pelajaran matematika siswa masih rendah, khususnya siswa kelas VIII E. Pada hasil Ulangan Tengah Semester Genap tahun pelajaran 2017/2018 terdapat 62,8\% siswa tidak tuntas, yaitu ada 22 siswa dari 35 siswa di kelas VIII E SMP Negeri 7 Tuban hasil belajarnya masih rendah yaitu memperoleh nilai kurang dari 75, sedangkan KKM kelas VIII di SMP Negeri 7 Tuban adalah 75.

Salah satu solusi untuk mengatasi masalah tersebut yaitu dengan menerapkan model pembelajaran tuntas dengan metode tutor sebaya. Model pembelajaran tuntas dengan metode tutor sebaya adalah inovasi pembelajaran yang dilaksanakan dengan sistematis dan memiliki tujuan agar materi yang dipelajari dapat dikuasai sepenuhnya oleh siswa dimana siswa yang tidak tuntas akan diadakan kegiatan remidi sampai semua siswa bisa menguasai materi secara tuntas. Selain itu pembelajaran juga lebih menarik karena dikombinasikan dengan metode tutor sebaya yaitu sekelompok siswa yang telah tuntas terhadap bahan pelajaran, memberikan bantuan kepada siswa yang mengalami kesulitan dalam memahami bahan pelajaran yang dipelajarinya. Merujuk Majid (2013), model pembelajaran tuntas merupakan suatu model pembelajaran yang tahapannya dilakukan secara terstruktur dan sistematis. Model pembelajaran ini sesuai diterapkan di kelas dengan jumlah siswa yang banyak. Selain itu model pembelajaran tuntas dapat membantu siswa untuk mengatasi perbedaan-perbedaan yang terdapat di kelas, khususnya kecepatan menguasai materi pelajaran dalam proses pembelajaran.

Menurut Indrianie (2015), metode tutor sebaya merupakan suatu proses pembelajaran dimana siswa yang memiliki hasil belajar tinggi didorong untuk menjadi tutor bagi siswa lain di kelompoknya. Metode pembelajaran ini akan memudahkan siswa yang memiliki hasil belajar rendah untuk memahami materi dengan lebih cepat karena adanya bantuan teman sebaya. Hasil penelitian menunjukkan bahwa metode tutor sebaya dapat meningkatkan hasil belajar matematika pada materi pengolahan data lebih baik daripada pembelajaran klasik (Ahdiyat, 2015; Izzati, 2015; Anistyani \& Radia, 2018). Tutor sebaya juga efektif meningkatkan hasil belajar siswa jika diterapkan secara berulang (Sinambela, 2015; Julianingsih, 2018). 
Oleh karena itu peneliti terdorong untuk mencoba menerapkan model pembelajaran tuntas dengan metode tutor sebaya pada siswa kelas VIII SMP Negeri 7 Tuban yang memiliki masalah pembelajaran matematika. Dengan mencoba menerapkan model pembelajaran tuntas dengan metode tutor sebaya, peneliti berharap dapat memecahkan masalah yang dihadapi siswa dalam proses pembelajaran matematika sehingga hasil belajar.

\section{METODE}

Jenis penelitian ini merupakan penelitian tindakan kelas (PTK). Penelitian tindakan kelas adalah penelitian yang dilakukan oleh guru ke kelas atau di sekolah tempat ia mengajar dengan penekanan pada penyempurnaan atau peningkatan proses dan praksis pembelajaran (Arikunto, 2013). Sesuai dengan karakteristik dari PTK, penelitian ini akan dilaksanakan dalam tiga siklus. Dalam setiap siklus terdapat empat tahapan yaitu perencanaan (planning), pelaksanaan tindakan (action), pengamatan (observation), refleksi (reflection).

Populasi penelitian ini adalah semua kelas VIII SMP Negeri 7 Tuban yang terdiri dari 8 kelas dengan masing-masing berjumlah 35 siswa. Subyek penelitian menggunakan hanya satu kelas yakni siswa kelas VIII E SMP N 7 Tuban semester genap tahun pelajaran 2017/2018 yang berjumlah 35 siswa. Penelitian ini dilakukan pada semester genap tahun pelajaran 2017/2018 yaitu pada tanggal 28 Maret - 16 April 2018.

Instrumen yang digunakan dalam penelitian ini yaitu tes hasil belajar dan lembar angket respon siswa. Bentuk tes evaluasi hasil belajar ini berupa tes uraian terdiri dari 2 soal. Angket respon siswa penelitian ini berjenis "check list" yang diberikan pada akhir pembelajaran. Teknik analisis data dalam penelitian ini adalah menggunakan teknik analisis deskriptif kuantitatif dan kualitatif. Data yang menggunakan analisis deskriptif kuantitatif adalah tes hasil belajar, sedangkan data yang menggunakan analisis deskriptif kualitatif adalah angket respon siswa.

\section{HASIL DAN PEMBAHASAN}

\section{Analisis Data Tes Hasil Belajar Matematika}

Analisis data tes hasil belajar bertujuan untuk memperoleh data ketuntasan hasil belajar matematika, maka siswa diberikan tes sesudah pembelajaran berlangsung dengan menggunakan tes hasil belajar matematika. Untuk menemukan keberhasilan belajar matematika siswa kelas VIII E SMP Negeri 7 Tuban maka hasil belajar matematika siswa akan dianalisis sesuai dengan pedoman penskoran.

Hasil analisis data diperoleh hasil belajar matematika siswa meningkat karena rata-rata kelas VIII E SMP Negeri 7 Tuban pada siklus I yang diperoleh adalah 88 dengan ketuntasan klasikal $100 \%$ pada siklus II rata-rata kelas hasil belajar matematika yang diperoleh adalah 89 dengan ketuntasan klasikal 100\%. Sedangkan pada siklus III tingkat rata-rata kelas hasil belajar matematika yang diperoleh adalah 97 dengan ketuntasan klasikal 100\%. Hal ini menunjukkan bahwa setiap siklus terjadi peningkatan. 
Tabel 1. Perbandingan Nilai Hasil Belajar Matematika Siswa

\begin{tabular}{cccc}
\hline \multirow{2}{*}{ Hasil Belajar Siswa } & \multicolumn{2}{c}{ Persentase (\%) } & \multirow{2}{*}{ Rata-rata } \\
\cline { 2 - 4 } & Tuntas & Belum Tuntas & 88 \\
\hline Siklus I & $100 \%$ & $0 \%$ & 89 \\
\hline Siklus II & $100 \%$ & $0 \%$ & 97 \\
\hline Siklus III & $100 \%$ & $0 \%$ & \multirow{2}{*}{$0 \%$} \\
\hline
\end{tabular}

Dari Tabel 1 menunjukkan adanya peningkatan hasil belajar matematika siswa terlihat dengan adanya selisih nilai rata-rata kelas pada siklus I, siklus II, dan siklus III. Selisih nilai rata-rata hasil belajar matematika pada siklus I ke siklus II sebesar 1 dan dari siklus II ke siklus III sebesar 8 . Peningkatan hasil belajar matematika tidak terlepas dari pembelajaran dengan menerapkan model pembelajaran tuntas dengan metode tutor sebaya yang menekankan hasil belajar matematika siswa, dengan demikian hasil belajar matematika siswa kelas VIII E SMP Negeri 7 Tuban dalam menyelesaikan tes evaluasi hasil belajar pada bangun ruang sisi datar lebih meningkat. Untuk mengetahui perbandingan pada setiap siklus dapat dilihat pada Gambar 1. Berdasarkan paparan di atas, dapat disimpulkan bahwa penerapan model pembelajaran tuntas dengan metode tutor sebaya dapat meningkatkan hasil belajar siswa kelas VIII E SMP Negeri 7 Tuban.

\section{Analisis Data Respon Siswa}

Data respon siswa terhadap penerapan model pembelajaran tuntas dengan metode tutor sebaya pada materi bangun ruang sisi datar di kelas VIII E SMP Negeri 7 Tuban tahun pelajaran 2017/2018 diperoleh dari angket siswa yang diberikan di akhir pembelajaran. Data respon siswa bertujuan untuk mengetahui pendapat siswa setelah menerapkan model pembelajaran tuntas dengan metode tutor sebaya. Data angket respon siswa adalah sebagai berikut :

Tabel 2. Respon Siswa terhadap Penerapan Model Pembelajaran Tuntas dengan Metode Tutor Sebaya pada Pokok Bahasan Bangun Ruang Sisi Datar Prisma dan Limas

\begin{tabular}{|c|c|c|c|}
\hline \multirow[b]{2}{*}{ No. } & \multirow[b]{2}{*}{ Pernyataan } & \multicolumn{2}{|c|}{ Pilihan Sikap } \\
\hline & & Setuju & $\begin{array}{l}\text { Tidak } \\
\text { Setuju }\end{array}$ \\
\hline 1. & Cara belajar yang baru saja berlangsung sangat menarik & $100 \%$ & $0 \%$ \\
\hline 2. & $\begin{array}{l}\text { Kesempatan berdiskusi dalam pembelajaran ini membuat saya lebih berani } \\
\text { mengemukakan pendapat }\end{array}$ & $100 \%$ & $0 \%$ \\
\hline 3. & $\begin{array}{l}\text { Dengan cara belajar seperti ini, membuat saya lebih menghargai pendapat } \\
\text { orang lain }\end{array}$ & $100 \%$ & $0 \%$ \\
\hline 4. & $\begin{array}{l}\text { Saya lebih mudah menyelesaikan tugas setelah menerima pembelajaran dengan } \\
\text { penerapan model pembelajaran tuntas dengan metode tutor sebaya }\end{array}$ & $86 \%$ & $14 \%$ \\
\hline 5. & $\begin{array}{l}\text { Proses pembelajaran membuat saya menjadi lebih aktif dalam kegiatan belajar } \\
\text { di kelas }\end{array}$ & $100 \%$ & $0 \%$ \\
\hline 6. & Proses pembelajaran membuat saya lebih merasa termotivasi & $100 \%$ & $0 \%$ \\
\hline 7. & $\begin{array}{l}\text { Proses pembelajaran membuat saya berani mengajukan pertanyaan pada guru } \\
\text { maupun teman }\end{array}$ & $100 \%$ & $0 \%$ \\
\hline \multirow[t]{2}{*}{8.} & $\begin{array}{c}\text { Saya lebih mudah memahami materi pokok bahasan bangun ruang sisi datar } \\
\text { prisma dan limas setelah menerima pembelajaran dengan penerapan model } \\
\text { pembelajaran tuntas dengan metode tutor sebaya }\end{array}$ & $83 \%$ & $17 \%$ \\
\hline & Rata-rata & $96 \%$ & $4 \%$ \\
\hline & Kualifikasi Keefektifan & \multicolumn{2}{|c|}{ Sangat Efektif } \\
\hline
\end{tabular}


Dari Tabel 2 di atas siswa dinyatakan senang dan berminat terhadap penerapan model pembelajaran tuntas dengan metode tutor sebaya, cara belajar $100 \%$, situasi pembelajaran $100 \%$, proses pembelajaran membuat siswa berani mengajukan pertanyaan pada guru maupun teman $100 \%$. Sedangkan untuk pendapat siswa lebih mudah menyelesaikan tugas setelah menerima pembelajaran dengan penerapan model pembelajaran tuntas dengan metode tutor sebaya sebesar 86\% dan pendapat siswa lebih mudah memahami materi pokok bahasan bangun ruang sisi datar prisma dan limas setelah menerima pembelajaran dengan penerapan model pembelajaran tuntas dengan metode tutor sebesar $83 \%$.

\section{PERSENTASE ANGKET RESPONSISWA}

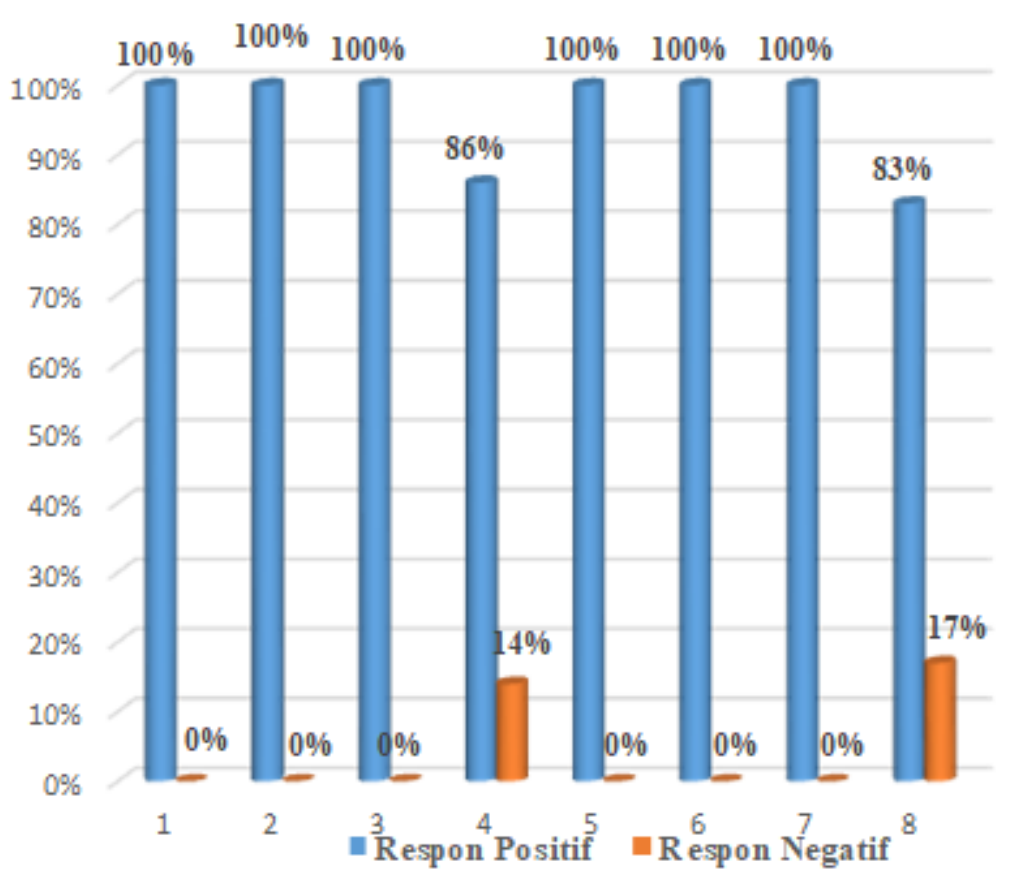

Gambar 1. Hasil Angket Respon Siswa

Berdasarkan Tabel 2 dan Gambar 1 dapat dilihat rata-rata persentase respon positif adalah 96\% dan respon negatif adalah $4 \%$. Ditinjau dari persentase yang didapatkan respon siswa dikatakan positif dan kategori sangat efektif dikarenakan persentase respon siswa terhadap penerapan model pembelajaran tuntas dengan metode tutor sebaya lebih dari atau sama dengan $85 \%$.

\section{KESIMPULAN}

Berdasarkan hasil analisis dapat disimpulkan sebagai berikut:

1. Rata-rata hasil belajar matematika siswa kelas VIII E SMP Negeri 7 Tuban semester II tahun pelajaran 2017/2018 pada siklus I adalah 88, siklus II adalah 89 dan siklus III adalah 97. Jadi ada peningkatan rata-rata hasil belajar matematika pada siklus I ke siklus II sebesar 1 dan dari siklus II ke siklus III sebesar 8. Serta persentase ketuntasan klasikal pada siklus I, II dan III mencapai $100 \%$.

2. Respon siswa terhadap penerapan model pembelajaran tuntas dengan metode tutor sebaya pada materi bangun ruang sisi datar dalam kriteria sangat efektif, dengan persentase respon positif sebesar $96 \%$. Sedangkan persentase respon negative sebesar $4 \%$. 


\section{DAFTAR RUJUKAN}

Ahdiyat, M. (2015). Metode Tutor Sebaya Untuk Meningkatkan Hasil Belajar Matematika Pada Materi Pengolahan Data. Faktor Jurnal Ilmiah Kependidikan, 1(2).

Anistyani, T. A., \& Radia, E. H. (2018). Pengaruh Pembelajaran Tutor Sebaya Terhadap Hasil Belajar Matematika Kelas V Sekolah Dasar. Jurnal Karya Pendidikan Matematika, 5(1), 15-22.

Arikunto, S. 2013. Prosedur Penelitian Suatu Pendekatan Praktik. Jakarta: Rineka Cipta

Indrianie, N. S. 2015. Penerapan Model Tutor Sebaya pada Mata Pelajaran Bahasa Inggris Reported Speech terhadap Hasil Belajar Peserta Didik MAN Kota Probolinggo. Jurnal Kebijakan dan Pengembangan Pendidikan, 3(1).

Izzati, N. (2015). Pengaruh Penerapan Program Remedial dan Pengayaan Melalui Pembelajaran Tutor Sebaya Terhadap Hasil Belajar Matematika Siswa. Eduma: Mathematics Education Learning and Teaching, 4(1).

Julianingsih, D. (2018). Upaya Meningkatkan Prestasi Belajar Siswa Matematika Melalui Strategi Pembelajaran Tutor Sebaya Dalam Penguasaan Bangun Datar Kelas VI SD Hidayatur Rohman Surabaya. Edumatika: Jurnal Riset Pendidikan Matematika, 1(1), 22-34. doi:10.32939/ejrpm.v1i1.219

Majid, A. 2016. Strategi Pembelajaran. Bandung: PT Remaja Rosdakarya

Purba, H. 2013. Penerapan Model Pembelajaran Tuntas untuk Meningkatkan Hasil Belajar Siswa Pada Mata Pelajaran Matematika Di Kelas VIII-I SMPN 1 Merek. Jurnal Saintech 5(1), 31-38

Sinambela, E. E. (2015). Meningkatkan Hasil Belajar Aljabar Siswa Dengan Menggunakan Metode Tutor Sebaya di SMP Negeri 175 Jakarta. Formatif: Jurnal Ilmiah Pendidikan MIPA, 4(1).

Ulandari, N., Putri, R., Ningsih, F., \& Putra, A. (2019). Efektivitas Model Pembelajaran Inquiry terhadap Kemampuan Berpikir Kreatif Siswa pada Materi Teorema Pythagoras. Jurnal Cendekia: Jurnal Pendidikan Matematika, 3(2), 227-237. 